\title{
ROSEMARY, MARJORAM AND GINGER AS A FEED ADDITIVES AND ITS INFLUENCES ON GROWTH PERFORMANCE TRAITS OF NZW RABBITS UNDER SINAI CONDITIONS
}

\author{
E. O. A.Bakr; I. M. M. Ibrahim; M. R. M. Mousa; M. M. Shetaewi and A. \\ M. Abdel-Samee \\ Department of Animal and Poultry Production, College of Environmental \\ Agricultural Sciences, Suez, Canal University, El-Arish, Egypt
}

\section{ABSTRACT:}

This study was carried out to evaluate the effects of either rosemary, marjoram or ginger on digestibility coefficients and growth performances traits of New Zealand White (NZW) rabbits under Sinai conditions. Seventy five weaned NZW rabbits were used in growth trial while, fifteen adult bucks were used in digestibility trials. The rabbits were divided into 5 similar and equal groups. The $1^{\text {st }}$ group fed control (CO) diet without medicinal plants, while those in the $2^{\text {nd }}, 3^{\text {rd }}, 4^{\text {th }}$ and $5^{\text {th }}$ groups were fed the pelleted diet containing 3\% rosemary, 3\% marjoram, $1.5 \%$ ginger root and $2.5 \%$ mixture $(1 \%, 1 \%$ and $0.5 \%)$ of these medicinal plants, respectively.

Daily body weight gain, feed conversion and dressing percentage improved $(P<0.05)$ by $11.63,1.73$ and $3.01 \%$ due to rosemary diet; 17.83, 22.66 and $4.01 \%$ due to marjoram diet; $15.70,11.35$ and $3.51 \%$ due to ginger diet and 22.56, 7.53 and $3.51 \%$ due to mixture diet, respectively. Digestibility coefficients of DM, OM, CP and EE were increased $(P<0.05)$ by 9.10, 6.36, 6.57 and $11.69 \%$ due to rosemary diet; 7.61, 6.66, 7.18 and $11.50 \%$ due to ginger diet and 7.41, 6.06, 6.14 and $9.61 \%$ due to mixture diet, respectively. The digestibility coefficients of CF and NFE were not significantly affected by supplemented medicinal plants. The nutritive values of TDN increased $(P<0.05)$ by $6.78 \%$ due to rosemary diet. From an economic point of view, diets supplemented with marjoram, ginger and mixture medicinal plants could be used efficiently in feeding growing NZW rabbits can reduce production costs.

Conclusively, the medicinal plants, Rosemary (Rosmarinus officinalis), Marjoram (Origanum majorana), Ginger root (Zingiber officinale) and their mixture could be added to NZW rabbit diets to improve growth performances traits and digestibility of nutrients under 
arid and semiarid conditions their addition within the limits recorded in this study is practically applicable, safe and beneficial.

Key words: Rabbits, Medicinal plants, Rosemary, Marjoram, Ginger, Growth, Carcass, Digestibility.

\section{INTRODUCTION}

Adding several products from different sources to rabbits feed is nowadays common and widely used for improving the utilization of nutrients, in order to improve performance (Boulos et al., 1992). Growth promoters (chemical products, antibiotics, enzymes, hormones, etc.) play an active role in the experimental and commercial production of large and small animals as well as rabbits. Although, good results were obtained with these substances, their use might have unfavorable effect (public health hazards and or environmental pollution). It may also, result in production of residual problems in the tissues of birds, rabbits and animals (Ogbuewu et al., 2011 and Abou Zied, 1998). However, using antibiotics as growth promoters and many artificial feed additives in rabbit production become internationally refused due to their adverse and side effects on human health (Marzo, 2001). It is indispensable to minimize these components, and deals with replacers without any adverse effect on production, so it is important to use natural substances that have no adverse effects on rabbit and human health (Abaza and El-Said, 2005). Great attention was, therefore focused on using natural feed additives such as herbs and medicinal plants in rabbit feeding.

Growth promoters from herbal sources (medicinal plants) are limited. Furthermore, little information about these materials is available. Many attempts have been made to use medicinal plants as feed additives to improve efficiency of feed utilization (Aboul-fotouh et al., 1999). Several studies showed that adding medicinal plants and herbs to the diets of rabbits, chicks, sheep, cows or buffaloes improved their feed intake, feed conversion and nutrient digestibility (Aboul-fotouh et al., 1999 and EL-Ayek, 1999), body weight, body weight gain, growth performance and mortality rate (Ibrahim, 2005 and Ibrahim, 2010), carcass traits (Evans and Pharm, 1975 and Ibrahim, 2010), physical conditions of gut ecosystem (Guo, 2003) and improved their immunity (Al-Beitawi et al., 2010).

Therefore, the objectives of the present study were to evaluate the effects of some dried medicinal plants such as Rosemary (Rosmarinus officinalis L.), Marjoram (Origanum majorana L.) and Ginger root (Zingiber officinale L.) on growth performance, carcass traits, digestibility of nutrients and economical efficiency of NZW rabbits under Sinai conditions. 


\section{MATERIALS AND METHODS}

Two experiments were carried out in the Rabbit Research Farm, Animal and Poultry Production Department, Environmental Agricultural Sciences College, Suez Canal University, at EL-Arish, North Sinai, Egypt, during June to August, 2014.

In experiment 1: A total of 75 weaned NZW rabbits (aged $35 \mathrm{~d}$ and weighed $660 \pm 12.9 \mathrm{~g}$ ) were divided into five comparable groups (15 from each group). The aim of this experiment was to study the effects of medicinal plants dietary treatments on growth performance, feeding value and carcass traits of growing NZW rabbits.

In experiment 2: A total of $15 \mathrm{NZW}$ rabbit bucks, aged 12-13 mo. and weighed $3.74 \pm 0.1 \mathrm{~kg}$ were divided randomly into five comparable groups (3 from each group). The aim of this experiment was to study the digestibility and nutritive values of the five dietary treatments. Table 1 presents the experimental design of the study.

The rabbits in the two experiments were divided into 5 equal groups; Rabbits in the $1^{\text {st }}$ group were fed the control $(\mathrm{CO})$ diet without medicinal plants, while those in the $2^{\text {nd }}, 3^{\text {rd }}, 4^{\text {th }}$ and $5^{\text {th }}$ groups were fed the pelleted diet containing $3 \%$ rosemary, $3 \%$ marjoram, $1.5 \%$ ginger root and $2.5 \%$ mixture $(1 \%, 1 \%$ and $0.5 \%)$ of these medicinal plants, respectively which were replaced with control diet at the same levels (\%) for each diet.

Table 1. Study experimental design.

\begin{tabular}{lccl}
\hline Items & $\begin{array}{c}\text { Rabbit } \\
\text { groups }\end{array}$ & $\begin{array}{c}\text { Number } \\
\text { of rabbits }\end{array}$ & \multicolumn{1}{c}{$\begin{array}{c}\text { Treatment } \\
\text { groups }\end{array}$} \\
\hline $\begin{array}{l}\text { Experiment I: } \\
\text { Effects of medicinal plants }\end{array}$ & $\mathrm{CO}$ & 15 & $\begin{array}{l}\text { Control diet } \\
\text { on growth traits. }\end{array}$ \\
& $\mathrm{RS}$ & 15 & $3 \%$ rosemary diet \\
& $\mathrm{ZR}$ & 15 & $3 \%$ marjoram diet \\
& $\mathrm{MX}$ & 15 & $1.5 \%$ ginger diet \\
& & & $0.5 \%$ ginger diet \\
\hline $\begin{array}{l}\text { Experiment II: } \\
\text { Digestibility and nutritive }\end{array}$ & $\mathrm{CO}$ & 3 & Control diet \\
values & $\mathrm{RS}$ & 3 & $3 \%$ rosemary diet \\
of dietary treatments. & $\mathrm{MR}$ & 3 & $3 \%$ marjoram diet \\
& $\mathrm{ZR}$ & 3 & $1.5 \%$ ginger diet \\
& $\mathrm{MX}$ & 3 & $1 \%$ rosemary, $1 \%$ marjoram and \\
& & & $0.5 \%$ ginger diet \\
\hline
\end{tabular}


Three medicinal plants from North Sinai spices markets were used in this study as follows: Rosemary (Rosmarinus officinalis L.), Marjoram (Origanum majorana L.), Ginger root (Zingiber officinale L.). These medicinal plants were grinded and then mixed with the diet. Five experimental diets were formulated to cover the nutrient requirements for rabbits according to (NRC, 1996). Ingredients of the pellets used and approximate analysis are shown in Table 2.

Table 2. Ingredients of experimental diets.

\begin{tabular}{lc}
\hline Ingredients & Control diet \\
\hline Alfalfa hay & 30.00 \\
Wheat bran & 29.00 \\
Yellow corn & 12.50 \\
Soybean meal (44\%) & 14.00 \\
Barley grain & 10.00 \\
Molasses & 2.00 \\
Calcium carbonate (lime stone) & 0.60 \\
Sodium chloride (salt) & 0.30 \\
Vitamins \& Mineral Premix* & 0.30 \\
DL-Methionine & 0.10 \\
Di-Calcium phosphate & 1.20 \\
\hline Total & $\mathbf{1 0 0 . 0}$ \\
\hline Calculated chemical composition & 18.128 \\
Crude protein (CP) & 2.936 \\
Ether extract (EE) & 12.17 \\
Crude fiber (CF) & 2768.3 \\
Digestible energy, (Kcal/Kg) & \\
\hline One kilogram of premix contain: Vit. A 12000 000 IU, Vit. D, 2200 00 IU, Vit. E 1000
\end{tabular}

- One kilogram of premix contain: Vit. A 12000000 IU, Vit. $D_{3} 220000$ IU, Vit. E 1000 mg, Vit. K 2000 mg, Vit. B 1000 mg, Vit. B 4000 mg, Vit. B 100 mg, Vit. $B_{12} 10$ $\mathrm{mg}$, Pantothenic acid $3.33 \mathrm{~g}$, Biotin $33 \mathrm{mg}$, Folic acid $0.83 \mathrm{~g}$, Choline chloride $200 \mathrm{~g}$, Zn 11.79 g, Mn 5 g, Fe 12.5 g, Cu 0.5 g, I 33.3 mg, Se $16.6 \mathrm{mg}$ and $\mathrm{Mg} 66.7 \mathrm{~g}$.

The rabbits were housed in galvanized wire cages in a well-ventilated (with open windows and ventilating fans). The cages were provided with feeders and automatic nipple drinkers. The grower rabbits were housed as 2 in each collective cage $(30 \times 40 \times 40 \mathrm{~cm})$. The bucks were housed in individual metabolic cages $(40 \times 55 \times 60 \mathrm{~cm})$. Each cage has stainless steel nipple for drinking and a feeder. The batteries were arranged in rows in the house. Rabbits were reared inside a building with windows used for natural ventilation and lighting. All animals received fresh water contained 705 ppm 
total dissolved solids (TDS) available automatically all the time by stainless steel nipples in each cage. All the experimental rabbits were healthy and clinically free from internal and external parasites and were kept under the same managerial and hygienic conditions.

Growth performance and feed utilization: The growth trial lasted for 60 days. The rabbits were individually weighed at the beginning of the experiment (6 weeks of age), then at weekly intervals at $8.00 \mathrm{~h}$. Feed consumption was recorded weekly using weight of feed consumption back technique and feed conversion efficiency (FCE) was calculated as the amount of feed consumed for production of unit body gain ( $\mathrm{kg}$ feed/ $\mathrm{kg}$ gain) Shetaewi (1998).

Carcass traits: At the end of the growth trial (95 days of age), a total of 70 rabbits were slaughtered to study the effect of dietary treatments on carcass traits. Animals were kept off feed overnight and body weights were recorded next morning prior to slaughter. After complete bleeding pelt were evaluated, hot carcass weight was obtained 15 to $30 \mathrm{~min}$ after slaughter and did not include blood, skin, distal part of tail, fore and hind legs (Shetaewi, 1998). Giblets weight (Liver, heart, kidneys weight), Dressing percentage $=[($ Hot carcass + Giblets weight) / pre slaughter weight] x 100 .

Metabolism trials: Biological assay was designed to evaluate differences in digestibility values of different nutrients (CP, E.E, C.F, NFE, ASH, DM and $\mathrm{OM}$ ) for the five experimental diets used in this study. The digestibility trial consisted of 10 day as a preliminary period followed by 7 days as a collection period. All rabbit bucks were weighed at the beginning and at the end of the collection period to make sure that their weights were maintained. The experimental diets were offered once a day at 8.00 a.m. ad libitum. The feces of rabbit bucks falling on a tray covered by plastic sheet at the bottom of the cage were quantitatively collected every day in the morning during the collection period every $24 \mathrm{~h}$ post- offering the daily feed, cleaned from fur and scattered feed. The dried feces (drying in an electric oven at $65 \mathrm{C}^{0}$ for 48 h) from each rabbit during the seven collection days were mixed together, weighed, finely grinded and kept in plastic vials for laboratorial analysis. Samples of medicinal plants, feeds and feces were chemically analyzed for their content of protein, fat, fiber and NFE (carbohydrate by difference) according to A.O.A.C. Methods (2005), and then the estimation was made as reported by Han et al., 1976. The NFE was calculated according to the following equation.

$$
\mathrm{NFE} \%=100-(\% \text { Moisture }+\% \mathrm{CP}+\% \mathrm{EE}+\% \mathrm{CF}+\% \mathrm{Ash})
$$


Digestibility values of nutrients of the experimental diets basis were estimated on DM basis. Values of TDN and DCP were calculated according to the classic formula described by Cheek et al. (1982), as follows:

$\mathrm{TDN} \%=\% \mathrm{DCP}+\% \mathrm{DCF}+\% \mathrm{DNFE}+2.25$ (\% DEE).

$\mathrm{DCP} \%=\mathrm{DP} \times \% \mathrm{CP} / 100$.

Economical evaluation: Economic efficiency is defined as the net revenue per unit feed cost calculated from input output analysis as described by Hassan et al. (1996).

The economic efficiency was calculated by the following:

Feed cost $=$ Number of $\mathrm{kg}$ feed per rabbit $X$ Price of $\mathrm{kg}$ feed.

Selling revenue $=$ Body weight gain per rabbit $\mathrm{X}$ Price of $\mathrm{kg}$ for live body weight rabbit.

Net revenue $=$ Difference between selling revenue and feed cost.

Economic efficiency $($ E.E $)=($ Net revenue/Total feed cost $) \times 100$.

Relative economic efficiency (R.E.E), assuming control treatment $=100 \%$.

The price of one $\mathrm{kg}$ of weanling live weight for meat rabbit and price of $\mathrm{Kg}$ feed in diets of control pelleted without M.P, RS, MR, ZR and MX were, $32.0,2.60,2.79,2.75,2.80$ and 2.78 L.E., respectively, during the experimental period (2014).

Statistical Analyses: Data were analyzed by Least-Squares Analysis of Variance using the General linear model (GLM) procedure of SAS (2004) according to Steel and Torrie (1980).

Data were analyzed by one way analysis of variance; $F$ value was significant $(\mathrm{P}<0.05)$ means were compared using the least significant difference (LSD) test.

\section{RESULTS AND DISCUSSION}

\section{Feeding values of medicinal plants:}

The chemical analysis of the three medicinal plants (MP) used in this study, are shown in Table 3. Marjoram had the highest percentages of crude protein $(\mathrm{CP})$, crude fiber $(\mathrm{CF})$ and ash compared to the other medicinal plants. Rosemary had the highest percentage of ether extract (EE) and Ginger had highest percentage of nitrogen free extract (NFE) as shown in Table 3.

Results presented in Table 3 showed that the values of CP, EE, NFE and ash in Rosemary were lower than those reported by Radwan (2003) and Ghazalah and Ali (2008), but values of CP and EE were higher than those of the reported by Osman_Mona et al. (2010). Value of NFE was higher than those reported by the same authors. 
Table 3. Chemical analysis (\%) of medicinal plants and the experimental diets.

\begin{tabular}{lccccccc}
\hline \multirow{2}{*}{ Items } & \multirow{7}{*}{ DM } & \multicolumn{7}{c}{ \% DM basis } \\
\cline { 3 - 8 } & & OM & CP & EE & CF & NFE & ASH \\
\hline Rosemary & 91.69 & 94.59 & 4.13 & 11.64 & 13.37 & 65.45 & 5.41 \\
Marjoram & 91.41 & 84.22 & 14.18 & 4.14 & 15.22 & 50.68 & 15.78 \\
Ginger root & 90.12 & 94.34 & 9.38 & 4.04 & 11.28 & 69.64 & 5.66 \\
\multicolumn{6}{l}{ Chemical composition of experimental diets given to NZW rabbits. } & & \\
CO & 91.89 & 89.42 & 18.21 & 3.04 & 12.05 & 56.12 & 10.58 \\
RS & 92.34 & 89.58 & 17.79 & 3.29 & 12.09 & 56.39 & 10.43 \\
MR & 92.33 & 89.26 & 18.09 & 3.07 & 12.15 & 55.96 & 10.74 \\
ZR & 90.95 & 89.65 & 17.81 & 3.01 & 11.86 & 55.48 & 10.35 \\
MX & 91.87 & 89.75 & 17.45 & 3.05 & 11.74 & 54.59 & 10.25 \\
\end{tabular}

$\mathrm{CO}$; Control, pelleted diet.

RS; Pelleted diet containing 3\% rosemary.

MR; Pelleted diet containing 3\% marjoram. ZR; Pelleted diet containing $1.5 \%$ ginger roots.

MX; Mixture, pelleted diet containing 1\% Rosemary $+1 \%$ Marjoram $+0.5 \%$ Ginger root.

In addition, values of $\mathrm{CP}, \mathrm{EE}$ and $\mathrm{CF}$ in Marjoram was higher than those reported by Osman_Mona et al. (2010) and Abdo_Zeinab et al. (2003), but it was lower than those reported by Abaza (2001), moreover, value of NFE was higher than those of the same authors. Similarly, values of CP, EE, CF and NFE in Ginger were higher than those reported by Allak et al. (2007) and Al-Kattan et al. (2008), but values of CP, EE and ash were lower than those reported by Ibrahim (2010) and Zomrawi et al. (2012).

Differences in the chemical composition that were found among reports could be attributed to differences in environmental conditions (local of plantation), ecological zone, age of harvesting, season of planting and harvesting, agronomic practices adopted, sample preparation and methods of analysis but remained, however the slight range relatively within. In general, the differences in chemical composition that were found among experimental diets (Table 3) could be attributed to differences between nutrients content of medicinal plants.

\section{Growth performance traits and economical efficiency:}

Data presented in Table, 4 indicated that, feeding growing NZW rabbits on RS, MR, ZR and MX diets increased $(\mathrm{P}<0.05)$ final body weight and daily body weight gain compared with control $(\mathrm{CO})$ group. This may be attributed to increase in feed intake or to the antimicrobial activity of the medicinal plants (Burt, 2004 and Tipu, et al., 2006). The antimicrobial mode of action is considered to arise mainly from the potential of the 
BAKR et al. 
hydrophobic essential oils to intrude into the bacterial cell membrane, disintegrate membrane structures, and cause ion leakage (Burt, 2004).

The improvement in growth performance traits due eating diets containing marjoram (Origanum majorana) may be attributed to the selective stimulation of the growth and/or activity of intestinal bacteria associated with health and wellbeing (Gibson, 1999) which improved nutrient utilization. Furthermore, the increase in growth performance in treated rabbits may be due to the role of Origanum majorana in increasing the concentrations of $\mathrm{Ca}$ and $\mathrm{Mg}$ in the colon. Elevated concentrations of these elements in the colon may help control the rate of cell turnover (Grizard and Barthomeuf, 1999). Origanum majorana may have anticarcinogenic and antimicrobial activities and also it may have activity in improving mineral absorption and balance. Besides that, Origanum majorana enhances the bioavailability and absorption of $\mathrm{Ca}$ and may affect the metabolism of other minerals, including $\mathrm{Mg}, \mathrm{Fe}$, and $\mathrm{Zn}$. These minerals have basic functions in growth performance (Underwood and Suttle, 1999).

The present results are in agreement with Ibrahim (2010) who reported that feeding diets containing $1 \%$ ginger diet to growing NZW rabbits improved $(\mathrm{P}<0.05)$ body weight gain. Moreover, Seleem et al. (2007) found that, supplementing 3\% Origanum majorana to the diet caused significant $(\mathrm{P} \leq 0.05)$ increases in daily weight gain and final body weight of growing NZW rabbits. In this respect Osman_Mona et al. (2010) indicated that feeding broiler diets supplemented with marjoram (Origanum majorana) and rosemary (Rosmarinus officinalis) diets increased body weights $(\mathrm{P} \leq 0.05)$ at the level $(1 \mathrm{~g} /$ $\mathrm{kg}$ diet) than those fed the control diet during the growth period. Moreover, Abd El-Galil (2007) found that feeding Japanese quail on 0.5, 1.0 and $1.5 \mathrm{gm}$. Origanum majorana leaves $/ \mathrm{kg}$ diet improved $(\mathrm{P} \leq 0.05)$ body weight and body weight gain when compared with the control. In sheep, Mohamed et al. (2005) found that rosemary (Rosmarinus officinalis) diet improved the average daily gain in lambs.

Contrary to the present results Omage et al., (2007) indicated that the growth performance of rabbits fed various levels of ginger (Zingiber officinale) in the diets did not significantly affect weight gain or final live weight.

Data presented in Table, 4 showed that, daily feed intake tended to increase as a function of feeding rosemary (RS), ginger (ZR) and the mixture (MX) in growing rabbits by $9.8,3.9$ and $14 \%$, respectively more than control group. While, marjoram (MR) reduced feed intake by $3.9 \%$ compared with the control. This may be attributed to that medicinal plants could have stimulated the appetite of rabbits, enhanced the process of digestion and absorption of food and encouraged secretion of different digestive enzymes of the stomach. While, 
the decrease in feed intake by adding marjoram to the diet may be due to an increase in the efficiency absorption and/or utilization of nutrients (Seleem et al., 2007).

Feeding growing rabbits on rosemary (RS), marjoram (MR), ginger (ZR) and mixture (MX) decrease feed conversion by 1.73, 22.66, 11.4 and $7.54 \%$, respectively compared with the control group (Table, 4). This may be attributed to the higher digestibility, which recorded particularly for groups supplemented by medicinal plants (RS, ZR and MX) which led to increase the absorbed nutrients from small intestine, consequently increase body weight gain and efficiency of feed utilization; and the higher average daily gain of the experimental groups than the control group. In addition to, the improvement in feed conversion efficiency due feeding diets containing marjoram could be to flavonoids. Flavonoids, as one component of marjoram, may influence the intestinal micro flora, resulting in better nutrient utilization and absorption. Another positive influence of flavonoids is their effect in improving feed conversion efficiency (Varilek et al, 2001), which is attributed to their antimicrobial, anti-fungal and antiflammatory effects. These characteristics of flavonoids would reduce mold growth and can completely inhibit the formation of aflatoxins, which would lead to higher efficiency of nutrients utilization in the feed.

These results are in agreement with those obtained by Seleem et al., (2007) found that, supplementation with 3\% Origanum majorana to the diets of NZW growing rabbits caused significant $(\mathrm{P} \leq 0.05)$ decreased in feed intake and feed conversion values compared to the untreated group. In addition, Osman_Mona et al. (2010) found that feed conversion ratio was decreased due to feeding broilers with marjoram (Origanum majorana) at the level of $1 \mathrm{~g} / \mathrm{kg}$ diet compared with the control. Ibrahim (2010) reported that feeding diets containing $1 \%$ ginger to growing NZW rabbits improved $(\mathrm{P}<0.05)$ daily feed intake and feed conversion efficiency. Also, Omage et al. (2007) indicated that feed intake increased significantly in rabbits fed ginger (Zingiber officinale) over those fed the control diet. In contrast Osman_Mona et al. (2010) indicated that feeding broilers with rosemary (Rosmarinus officinalis) at the level of $1 \mathrm{~g} /$ $\mathrm{kg}$ diet reduced $(\mathrm{P} \leq 0.05)$ feed consumption compared with other treatments. Mohamed et al. (2005) found that rosemary (Rosmarinus officinalis) in rations improved feed conversion for lambs as DMI $\mathrm{kg} / \mathrm{kg}$ body gain: as a result to increase feed utilization.

Economical efficiency: Relative economic efficiency (REF) increased 129.7, 108.8 and 104.2, respectively compared with (100\%) in CO due to feeding the growing rabbits on MR, ZR or MX when compared with the $\mathrm{CO}$ diet. In the contrary, feeding RS decreased relative economic efficiency 
compared with the CO (Table, 4). The same trend was obtained by Ibrahim (2010) who reported that feeding diets containing 1\% ginger to growing NZW rabbits increased $(\mathrm{P}<0.05)$ REF. Moreover, Abd El-Galil (2007) found that feeding the Japanese quail on level $0.5,1.0$ and $1.5 \mathrm{gm}$. Origanum majorana leaves per $\mathrm{kg}$ of diet improved $(\mathrm{P} \leq 0.05)$ economic efficiency as compared with the control group. Also, Osman_Mona et al. (2010) indicated that feeding broiler on Origanum majorana at $1 \mathrm{~g} / \mathrm{kg}$ diet increased their economic efficiency (\%) as compared with the control diet.

\section{Carcass traits:}

Results of carcass traits (Table 5) show that rabbits supplemented with medicinal plants had higher $(\mathrm{P}<0.05)$ pre-slaughter weight than those fed the $\mathrm{CO}$ diet. Rabbits fed the MX diet had the highest value of all treatment groups. In addition, carcass weight increased $(\mathrm{P}<0.05)$ in RS, MR, ZR and MX (1293 to 1403 gm.) treatment groups, where as MR was similar to the CO group (1159 gm.). Also, dressing \% increased $(\mathrm{P}<0.05)$ in treated groups $(61.6$ to $62.2 \%)$ compared with the control $(59.8 \%)$.

Data presented in Table, 5 showed that head, liver, kidney, heart and lungs weights did not differ significantly $(\mathrm{P}<0.05)$ among treatments. However, full gut wt. was decreased by feeding medicinal plants compared with the control.

These results may be attributed to growth promoting effects of medicinal plants and to enhancement of metabolism of essential and volatile oils included in medicinal plants (Evans and Pharm, 1975). In addition to increased daily weight gain (Table, 5) besides the effect of antimicrobial properties of medicinal plants (Tipu, et al., 2006; Jiang et al., 2006). The increase in carcass traits for treated group may be mainly related to the increase in growth performance trits. Therefore, pre-slaughter weight is considered to be one of the most important factor affecting carcass traits in rabbits. Maertens and Groote (1992) reported the important effect of pre-slaughter body weight on carcass traits.

In this connection, Seleem et al. (2007) reported that 3\% Origanum majorana treatment caused $19.0 \%$ increase $(\mathrm{P} \leq 0.05)$ in dressing percentage and also the giblets of internal organs weight such as kidney; liver and heart was increased in growing NZW rabbits. In addition, Osman_Mona et al. (2010) indicated that feeding rosemary (Rosmarinus officinalis) to broiler at $1 \mathrm{~g} / \mathrm{kg}$ of diet increased $(\mathrm{P} \leq 0.05)$ their carcass weight than the control diet. Ibrahim (2010) who reported that feeding diets containing $1 \%$ ginger to growing NZW rabbits increased $(\mathrm{P}<0.05)$ dressing percentage and carcass traits. In contrast, Omage et al., (2007) indicated that the dressing percentage of rabbits fed various levels of ginger (Zingiber officinale) in their diets had no significant effects $(\mathrm{P}>0.05)$. 
Table 5. Carcass quality of growing NZW rabbits fed diets supplemented with medicinal plants (LS-means \pm SE).

\begin{tabular}{lcccccc}
\hline \multirow{2}{*}{ Items } & \multicolumn{5}{c}{ Experimental diets } & \\
\cline { 2 - 6 } & CO & RS & MR & ZR & MX & \multirow{2}{*}{ SEM } \\
\hline Carcass traits : & & & & & & \\
Pre-slaughter wt., gm & $1939^{\mathrm{c}}$ & $2097^{\mathrm{b}}$ & $2146^{\mathrm{b}}$ & $2139^{\mathrm{b}}$ & $2254^{\mathrm{a}}$ & 22.98 \\
Hot wt., gm & $1886^{\mathrm{c}}$ & $2037^{\mathrm{b}}$ & $2090^{\mathrm{b}}$ & $2083^{\mathrm{b}}$ & $2181^{\mathrm{a}}$ & 21.57 \\
Carcass wt., gm & $1159^{\mathrm{b}}$ & $1335^{\mathrm{a}}$ & $1293^{\mathrm{a}}$ & $1325^{\mathrm{a}}$ & $1403^{\mathrm{a}}$ & 20.50 \\
Dressing \% & $59.8^{\mathrm{b}}$ & $61.6^{\mathrm{a}}$ & $62.2^{\mathrm{a}}$ & $61.9^{\mathrm{a}}$ & $62.2^{\mathrm{a}}$ & 0.478 \\
Head wt., gm & 124.5 & 122.9 & 129.2 & 127.5 & 130.9 & 3.64 \\
Liver wt., gm & 53.5 & 59.3 & 59.8 & 51.9 & 58.3 & 2.74 \\
Kidneys wt., gm & 14.3 & 14.4 & 15.4 & 13.6 & 15.99 & 0.90 \\
Heart \& Lungs wt., gm & 18.7 & 18.3 & 19.8 & 19.0 & 19.7 & 1.45 \\
Full gut wt., gm & $226.8^{\mathrm{a}}$ & $211.6^{\mathrm{ab}}$ & $212.9^{\mathrm{ab}}$ & $212.7^{\mathrm{ab}}$ & $207.4^{\mathrm{b}}$ & 6.16 \\
\hline
\end{tabular}

${ }_{a, b, \text { andc }}$ : Means within the same row with different superscripts differ $(\mathrm{P}<0.05), \mathrm{SE}=$ standard error. $\mathrm{CO}=$ Control; $\mathrm{RS}=$ Rosemary; $\mathrm{MR}=$ Marjoram; $\mathrm{ZR}=$ Ginger; $\mathrm{MX}=$ mixture of $\mathrm{RS}, \mathrm{MR}$ and $\mathrm{ZR}$.

\section{Digestibility coefficients and nutritive values of dietary treatments:}

Digestion of nutrients coefficients and nutritive values of the experimental diets are shown in Table, 6. In general, digestibility coefficients of DM, OM, CP and EE increased significantly $(\mathrm{P}<0.05)$ by feeding mature NZW rabbit bucks on RS, ZR and MX diets as compared with the control diet, but did not differ significantly when feeding of MR diet. On the other hand, digestion coefficients of CF and NFE showed no significant differences among treatment groups.

The improvements of digestibility coefficients may be due to medicinal plants content of biological constituents, such as antioxidants, essential oils, flavonoids and antimicrobial activity (Burt, 2004) which had beneficial effects for stimulated the appetite of rabbits, enhanced the process of digestion and absorption of food and encouraged secretion of different digestive enzymes of the stomach (Tipu et al., 2006) and activity of caecum fermentation (Ibrahim, 2005). In this concern, ginger diets have been reported to enhance animals' nutrient digestion and absorption because of the positive effects on the gastric secretion, enterokinesia and digestive enzyme activities (Platel and Srinivasan, 2000). Furthermore, Caspary (1992) suggested that the increase in long villi would increase the surface area that is capable of great absorption of available nutrients by ginger diet. While, greater villus height and more numerous cell mitosis in the intestine are indicators that the function of intestinal villi is activated (Yasar and Forbes, 1999). 
Table 6. Digestion coefficients (\%) and nutritive values (\%) of the experimental diets (LS-means \pm SE).

\begin{tabular}{lcccccc}
\hline \multirow{2}{*}{ Items } & \multicolumn{5}{c}{ Experimental diet $^{*}$} & \\
\cline { 2 - 5 } & CO & RS & MR & ZR & MX & ISEM \\
\hline Digestion coefficients (\%) & & & & \\
DM & $62.78^{\mathrm{b}}$ & $68.49^{\mathrm{a}}$ & $65.47^{\mathrm{ab}}$ & $67.56^{\mathrm{a}}$ & $67.43^{\mathrm{a}}$ & 1.24 \\
OM & $68.04^{\mathrm{b}}$ & $72.37^{\mathrm{a}}$ & $70.02^{\mathrm{ab}}$ & $72.57^{\mathrm{a}}$ & $72.16^{\mathrm{a}}$ & 1.08 \\
$\mathbf{C P}$ & $72.43^{\mathrm{b}}$ & $77.19^{\mathrm{a}}$ & $75.08^{\mathrm{ab}}$ & $77.63^{\mathrm{a}}$ & $76.88^{\mathrm{a}}$ & 0.87 \\
EE & $72.09^{\mathrm{b}}$ & $80.52^{\mathrm{a}}$ & $70.20^{\mathrm{b}}$ & $80.38^{\mathrm{a}}$ & $79.02^{\mathrm{a}}$ & 0.86 \\
CF & 38.28 & 42.42 & 42.11 & 42.91 & 43.73 & 1.95 \\
NFE & 72.78 & 76.79 & 74.43 & 76.12 & 75.51 & 1.01 \\
Nutritive & value (\%) & & & & & \\
\hline TDN & $63.58^{\mathrm{b}}$ & $67.89^{\mathrm{a}}$ & $65.20^{\mathrm{ab}}$ & $66.59^{\mathrm{ab}}$ & $65.19^{\mathrm{ab}}$ & 0.95 \\
DCP & 13.19 & 13.73 & 13.58 & 13.82 & 13.42 & 0.16 \\
\hline
\end{tabular}

${ }^{\text {ando }}$ : Means within the same row with different superscripts differ $(\mathrm{P}<0.05), \mathrm{SE}=$ Standard error. $* \mathrm{CO}=$ Control; $\mathrm{RS}=$ Rosemary; $\mathrm{MR}=$ Marjoram; $\mathrm{ZR}=$ Ginger; $\mathrm{MX}=$ mixture of $\mathrm{RS}, \mathrm{MR}$ and $\mathrm{ZR}$.

The present results are in agreement with those of Ibrahim (2010) who reported that feeding diets containing $1 \%$ ginger to NZW rabbit bucks increased digestibility coefficients of DM; OM; CP and EE. In addition, Abd El-Galil and Henda (2015) indicated that addition of ginger at 0.5 and $0.75 \mathrm{~g} / \mathrm{kg}$ diet to Japanese quail had a significant effect on improving digestibility coefficients and nutritive values. Similarly, Ibrahim et al. (2009) found in growing lambs that adding $1 \%$ or $2 \%$ of herb mixture containing ginger significantly improved DM and $\mathrm{OM}$ digestibility values as compared to the control group.

The same trend was obtained by Mohamed et al. (2003) who fed ewes on $150 \mathrm{mg}$ rosemary/kg live body weight and recorded higher values of nutrients digestibility for $\mathrm{DM}, \mathrm{OM}, \mathrm{CP}$ and $\mathrm{EE}$ than the control group. In addition, Mohamed et al. (2005) observed that digestion coefficients were significantly higher for DM, OM and CP with Rosmarinus officinalis when compared with control ration of ewes.

These results did not agree with those obtained by Mohamed et al. (2005) who observed that digestion coefficients were significantly higher for DM, OM and CP with Marjoram hortansia compared with control ration of ewes. Furthermore, Abd El-Galil (2007) found that feeding Japanese quail on 0.5, 1.0 and $1.5 \mathrm{gm}$. marjoram leaves $/ \mathrm{kg}$ diet improved $(\mathrm{P} \leq 0.05)$ digestibility coefficients of OM; CP; CF; EE and NFE when compared with control group.

Concerning the nutritive values of experimental diets in Table 6 , the results showed that total digestible nutrients $(\mathrm{TDN})$ value was increased $(\mathrm{P}<0.05)$ for RS 
diet compared with the control diet, but did not differ significantly from the other treatment groups. While, the nutritive values of digestible crude protein (DCP) did not differ significantly among treatments. The same trend was obtained by Mohamed et al. (2003 and 2005) who observed that the TDN values were improved significantly as a result of rosemary (Rosmarinus officinalis) supplementation to the ration of ewes $(150 \mathrm{mg} / \mathrm{kg} \mathrm{LBW})$. In addition, Ibrahim (2010) reported that feeding diets containing 1\% ginger roots to NZW rabbit bucks increased DCP values, but did not differ significantly.

On the other hand, Abd El-Galil (2007) found that feeding Japanese quail at levels $0.5,1.0$ and 1.5 gm. marjoram leaves $/ \mathrm{kg}$ diet improved $(\mathrm{P} \leq 0.05)$ nutritive values calculated as TDN when compared with control group. Moreover, Ibrahim et al. (2009) found that adding $1 \%$ or $2 \%$ of herb mixture containing ginger significantly improved $(\mathrm{P} \leq 0.05)$ nutritive values calculated as TDN compared to the control group in growing lambs.

\section{In conclusion:}

The medicinal plants, Rosemary (Rosmarinus officinalis), Marjoram (Origanum majorana), Ginger root (Zingiber officinale) and their mixture could be added to NZW rabbit diets to improve growth performances traits and digestibility of nutrients under arid and semiarid conditions their addition within the limits recorded in this study is practically applicable, safe and beneficial.

\section{REFERENSES}

A.O.A.C. (2005). Association of Official Analytical Chemists. Official Methods of Analysis. " $17^{\text {th }}$ Ed. Published by the A.O.A.C. Washington, DC, USA.

Abaza, I. M. (2001). The use of some medicinal plants as feed additives in broiler diets. Ph.D. Thesis, Fac. Agric., Alex. Univ., Egypt, 115pp.

Abaza, I. M. and El-Said, H. (2005). Effect of using Yucca schidigera as feed additive on performance of growing rabbits. Proceeding $4^{\text {th }}$ Int. Conf. Rabbit Production Hot Climates, 24-27 Febr., Sharm El-Sheik, Egypt, 259-266.

Abd El-Galil, K. (2007). Effect of some feed additives on performance of laying Japanese quail.1- Effect of Marjoram leaves meal as a feed additive in laying Japanese quail diets. J. Agric. Sci., Mansoura Univ., 32(7): 5167-5179.

Abd El-Galil, K. and Henda, A. M. (2015). Effect of Ginger roots meal as feed additives in laying Japanese quail diets. J. American Sci., 11(2): 164-173.

Abdo_Zeinab, M. A.; Soliman, A. Z. and Barakat, O. S. (2003). Effect of hot pepper and Marjoram as feed additives on the growth performance and the microbial population of the gastro-intestinal tract of broilers. Egypt, Poult. Sci., 23 (I): 91-113. 
Abou Zied, M. R. (1998). Evaluation of some medicinal plants as a feed additive in diets of Nile Tilapia. M.Sc. Thesis, Fac. Agric., EL-Fayoum Univ., Egypt.

Aboul-fotouh, G. E.; Allam, S. M.; Shehat, E. and Abdel-Azeem, S. N. (1999). Effect of some medicinal plants as feed additives on performance of growing sheep. Egypt. J. Nutr. And Feeds, 2: 79-87.

Al-Beitawi, N. A.; El-Ghousein, S. S. and Athamneh, M. Z. (2010). Effect of adding crushed Pimpinella anisum, Nigella sativa seeds and Thymus vulgaris mixture to antibiotics-free rations of vaccinated and non-vaccinated male broilers on growth performance, antibody titer and haematological profile. Ital. J. Anim. Sci., 9: e43, 222-228.

Al-Kattan, M. M.; Abdul-Fattah, J. H. and Al-Hadidy, A. A. (2008). Effect of Zingiber officinale rhizomes powder on some physiological, histological and biochemical features in White male rabbits. Alrafidain J. Sci., 19 (2): 72-84.

Allak, M. A. (2007). Amelioration of heat stress by using some medicinal herbs and electrolytes and their effects on semen characteristics of Ossimi rams. M. Sc. Thesis, Fac. Agric, Fayoum, Univ., Egypt, 117pp.

Boulos, N. Z.; El-Skeikh, M. A; Abdella, H. M. and Hattaba, N. A. (1992). Effect of the biogenic enhancer Ascogenr on laying hen performance. Egypt. Poultry Sci., 12 (II): 679-695.

Burt, S. (2004). Essential oils: their antibacterial properties and potential applications in foods-a review. Int. J. Food. Microbiol. 94: 223-253.

Caspary, W. F. (1992). Physiology and pathophysiology of intestinal absorption. Am. J. Clin. Nutr. 55(Suppl. 1):299-308.

Cheek, P. R.; Patton, N. M. and Tempelton, G. S. (1982). Rabbit Production. $5^{\text {th }}$ Ed. Print and Published. USA.

EL-Ayek, M. Y. (1999). Influence of substituting concentrate feed mixture by Nigella sativa meal on: 1- Voluntary intake, digestibility, some rumen parameters and microbial protein yield with sheep. Egypt. J. Nutr. and Feeds, 2: 279-296.

Evans, F. J. and Pharm, B. (1975). Herbs, A Concise Guide. (Cited by Abd ElLatif et al., 2002).

Ghazalah, A. A. and Ali, A. M. (2008). Rosemary leaves as a dietary supplement for growth in broiler chickens. Int. J. Poult. Sci., 7 (3): 234-239.

Gibson, G. R. (1999). Dietary modulation of the human gut microflora using the prebiotics oligofructose and inulin. Anim. Soc. Nutr. Sci., 129: 1438-1441.

Grizard, D. and Barthomeuf, C. (1999). Non-digestible oligosaccharides used as prebiotic agents: mode of production and beneficial effects on animal and human health. Reprod. Nutr. Dev., 39:563-588. 
Guo, F. C. (2003). Mushroom and herb polysaccharides as alternative for antimicrobial growth promoters on poultry. Ph.D. Thesis, Wageningen Institute of Animal Sciences, Dep. Anim. Nutr., Wageningen Univ., Wageningen, Netherlands.

Han, I. K.; Hochsteler, H. W. and Scott, M. I. (1976). Metabolizable energy value of some poultry feeds determined by various methods and their estimation using metabolizability of dry matter. Poultry Sci., 55: 1335-1342.

Hassan, I.; Abdallah, A. G. and Abo El-wafa, S. (1996). Utilization of decorticated local cottonseed meal in broiler diets. Egyptian Poultry Sci., (16): 31-49.

Ibrahim, A. M. ; Abedo, A. A; Omer, H. A. and Ali, F. A. (2009). Response of growing New Zealand White rabbits to diets containing different levels of energy and mixture of some medicinal plants. World J. Agric. Sci., 5(5): 544-551.

Ibrahim, M. M. (2010). Effect of some untraditional diets on growth, reproduction and carcass characteristics of rabbits in North Sinai. M. Sc. Thesis, Fac. Environ. Agric. Sci., Suz Canal Univ., Egypt, 112pp.

Ibrahim, Sh. A. M. (2005). Effect of some medicinal plants as feed additives on growth and some metabolic changes in rabbits. Egyptian J. Nutr. and Feeds, 8: 207-219.

Jiang, H.; Xie, Z.; Koo, H. J.; McLaughlin, S. P.; Timmermann, B. N. and Gang, D. R. (2006). Metabolic profiling and phylogenetic analysis of medicinal Zingiber species: Tools for authentication of ginger (Zingiber officinale Roscoe). Phytochemistry, 67: 232-244.

Maertens, S. L. and Groote, G. D. (1992). Study of the influence of slaughter weight on carcass traits and carcass composition of rabbits. Revue de L Agric., 45(1): 59-70.

Marzo, I. (2001). New strategies in rabbit feed: Additives and alternatives to antibiotic use. $26^{\text {th }}$ Symp. ASESCU, Aveiro, (Portugal), 51-68.

Mohamed A. H.; Abd El-Bar, N. M. and Ibrahim, K. (2005). Influence of some medicinal plants supplementation on: 2- lambs performance, carcass properties and mutton meat quality. Egyptian J. Nutr. and Feeds, 8 (1): 445.

Mohamed A. H.; El-Saidy, B. E. and El-Seidi, I. A. (2003). Effect of some medicinal plants supplementation on: 1- digestibility, nutritive value, rumen fermentation and some blood biochemical parameters in sheep. Egyptian $J$. Nutr. and Feeds, 6(2): 139.

NRC (1996). National Research Council. Nutrient Requirements of Rabbits. Washington, DC. USA.

Ogbuewu, I.P.; Odoemelam, V.U.; Obikaonu, H.O.; Opara, M.N.; Emenalom, O.O.; Uchegbu, M.C.; Okoli, I.C.; Esonu, B.O. and Iloeje, M.U. (2011). The growing importance of neem in agriculture, industry, medicine and environment: A Review. Res. J. Med. Plants, 5:230-245. 
Omage, J. J.; Onimisi, P. A.; Adegbite, E. K. and Agunbiade, M. O. (2007). The effect of ginger (zingiber officinale Roscoe) waste meal on growth performance, carcass characteristics, serum lipid and serum cholesterol profiles of rabbit. Pakistan J. Nutr., 6(4): 359-362.

Osman_Mona, M. T.; Yakout, H. M.; Motawe, H. F. and Ezz El-Arab, W. F. (2010). Productive, physiological, immunological and economical effects of supplementing natural feed additives to broiler diets. Egypt. Poultry Sci., 30(I): 25-53.

Platel, K. and Srinivasan, K. (2000). Influence of dietary spices and their active principles on pancreatic digestive enzymes in albino rats. Nahrung, 44(1): 4246.

Radwan, N. L. (2003). Effect of using some medicinal plants on performance and immunity of broiler chicks. Ph.D. Thesis, Fac. Agric., Cairo Univ., Egypt, 146 pp.

SAS (2004). SAS procedures Guide for personal Computers., Statistical Analysis System Institute, SAS Institute Inc., Cary, N.C.

Seleem, T. S.T.; Ibrahim, H.; Ali, A. M.; Abd-Elmotaal, A. M. and Zeidan, A. E. B. (2007). Rabbit performance as affected by Origanum majorana in diets. $5^{\text {th }}$ Int. Conf. Rabbit Production in Hot Climates, 8-10 Oct., Hurghada, Egypt, 495-508

Shetaewi, M. M. (1998). Efficiency of dietary high levels of antioxidant vitamins C and E for rabbits subjected to crowding stress. Egyptian J. Rabbit Sci., 8 (2), 95-112.

Steel, R. G. D. and Torrie, J. H. (1980). Principles and Procedures of Statistics: A Biometrical Approach (2nd Ed.). McGraw-Hill Book Co., New York.

Tipu, M. A.; Akhtar, M. S.; Anjum, M. I.; and Raja, M. I. (2006). Newdimension of medicinal plants as animal feed. Pakistan Vet. J., 26(3): 144-148.

Underwood, E. J. and Suttle, N. F. (1999). The Mineral Nutrition of Livestock. 3rd Edition, CAB Int. Publishing.

Varilek G. W.; Yang, F.; Lee, E. Y.; De Villiers, W. J. S.; Zhong, J.; Oa, H. S.; Westberry, K. F. and Mc-Clain, C. J. (2001). Green tea polyphenol extract attenuates inflammation in interleukin-2-different mice, a model of autoimmunity. J. Nutr., 131: 2034-2039.

Yasar, S. and Forbes, J. M. (1999). Performance and gastrointestinal response of broiler chicks fed on cereal gain-based foods soaked in water. Br. Poultry Sci., 40: 65-67.

Zomrawi, W. B.; Abdel Atti, Kh. A. and Dousa, B. M. (2012). The effect of ginger root powder (Zingiber officinale) supplementation on broiler chicks performance, blood and serum constituents. Online J. Anim. Feed Res., 2(6): 457-460. 


\section{نباتات الحصالبان والبردقوش والزنجبيل كإضافات غذائية وتأثير ها على فئى أداء النمو فى الأرانب تحت ظروف سئن سيناء}

السيد عثمان عبد التبى بكر، ابراهيم محمد محمد ابراهيم، محمد رضا موسىى،

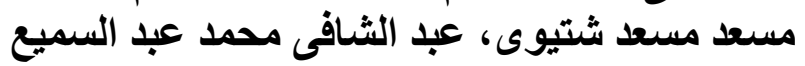

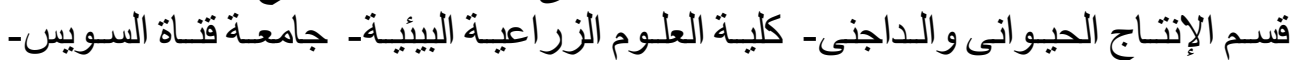

أجريت هذة الدر اسة بمزر عة الأر انب التابعة لقسم الانتاج الحيو انى و الداجنى، كلية القانية

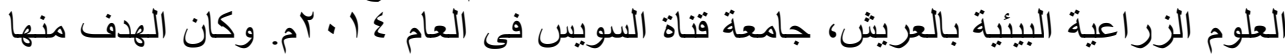

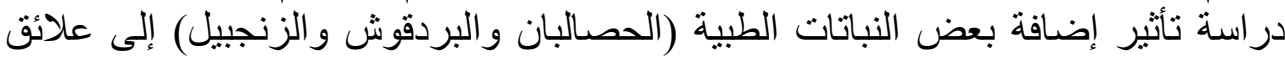

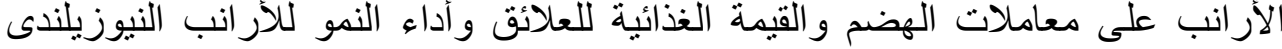

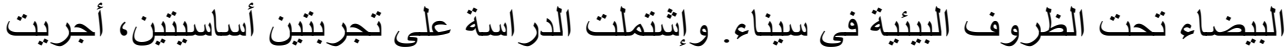

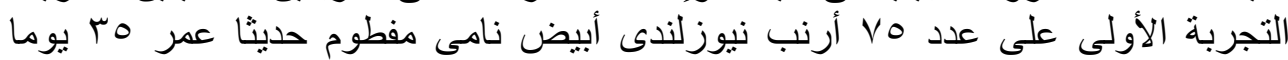

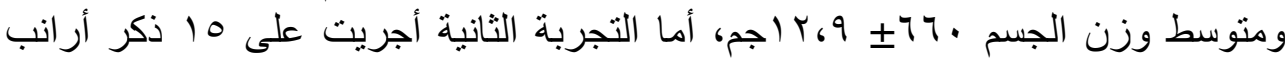

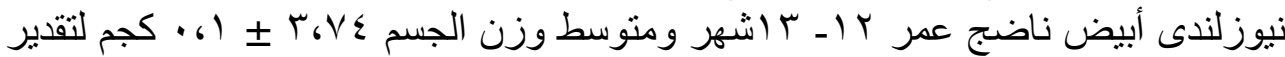

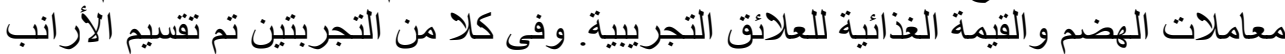

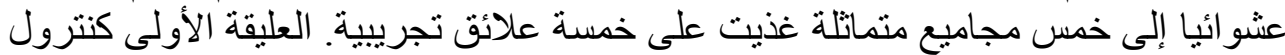

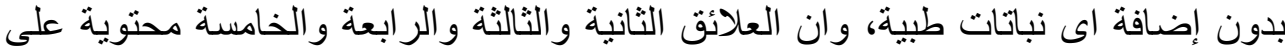

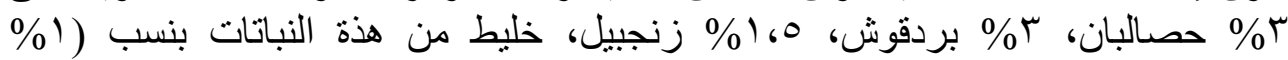

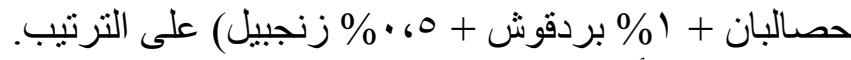

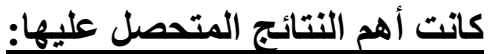

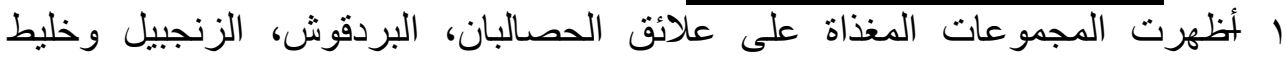

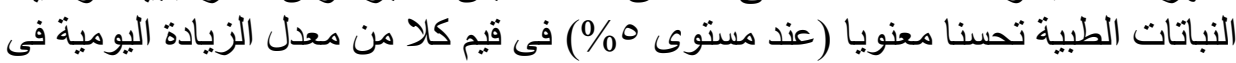

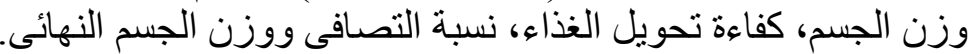

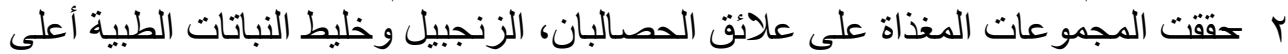

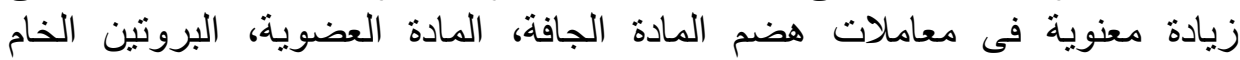

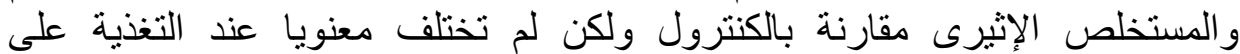

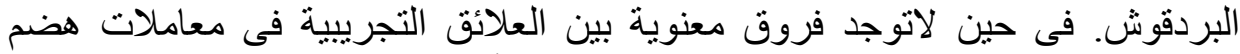

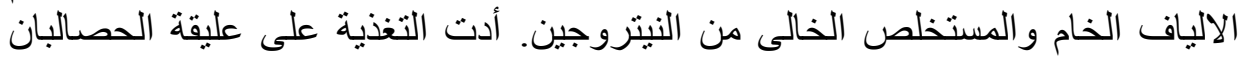

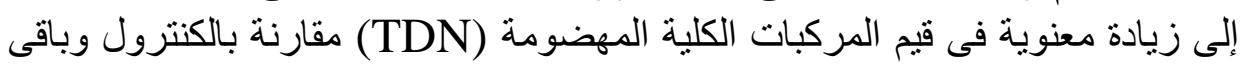
المجاميع التجريبية.

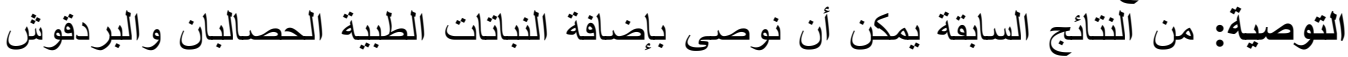

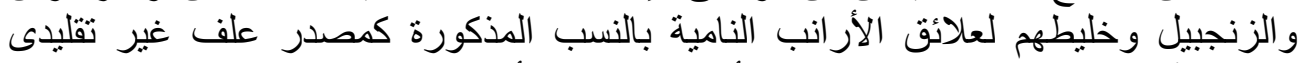
متوفر و آمن الإستخدام ومفيدا لتحسين الأداء الإنتاجى للأر الب النب النامية. 